\title{
Relationships of Total Coliform, Fecal Coliform, and Organic Pollution Levels in the Tamagawa River
}

\author{
Akira Hiraishr, ${ }^{* 1,2}$ Kazuaki SAHEKI, ${ }^{* 1}$ and Susumu HorIE*1
}

(Accepted October 4, 1983)

\begin{abstract}
Total coliform (TC) and fecal coliform (FC) organisms were enumerated and isolated from water samples from several stations on the Tamagawa River and its tributaries in Tokyo. The level of these indicator bacteria and biochemical oxygen demand (BOD) markedly increased from the upper streams towards the lower reaches of this river system. There were statistically significant positive correlations $(p<0.01)$ among TCs, FCs, and BOD. Also the FC/TC ratios were highly correlated with BOD $(p<0.01)$. The proportion of thermotolerant coliforms and Escherichia coli constituting the TC population increased with increasing BOD levels, whereas the relative concentration of $E$. coli to the FC population decreased with increasing BOD levels. These results suggest that the population densities of FCs or thermotolerant coliforms in the river environment are directly proportional to the degree of sewage and human waste pollution, which is reflected by BOD levels, but their occurrence in polluted river and estuary waters is due in part to regrowth of some FC members such as Klebsiella pneumoniae.
\end{abstract}

Analysis of the heterotrophic bacterial population in an aquatic system is of primary importance for evaluating its trophic conditions, ${ }^{1}$ as well as for assessing input of microorganisms from extraaquatic environments. It has been suggested that the number of free-living or sessile aerobic heterotrophic bacteria in freshwater environments is directly proportional to the degree of organic pollution, ${ }^{2-4)}$ as measured by the chemical or biochemical oxygen demand (BOD) analysis. On the other hand, the bacteriological quality of water has traditionally been assessed by monitoring the levels of total coliform (TC) and fecal coliform (FC) organisms and/or Escherichia coli. Also, the proportion of FCs constituting the TC population has been used to define possible sources of pollution or to indicate the time interval between initial pollution and bacteriological examination. $^{5-7)}$ In recent years, natural aquatic environments have been polluted as the result of receiving increasing nutrient loads. The increase in BOD levels in natural water bodies might greatly affect the populations and survival of these indicator bacteria. It is therefore of interest to observe the relationships of TCs, FCs, and BOD in the aquatic environment. Although some workers have noted a direct relationship between the TC population and BOD in polluted river and estuary waters, ${ }^{8)}$ detailed information available on this subject is limited.

The Tamagawa River is typical of the watershed system of freshwater rivers in Japan, and has increasingly received inflow of domestic sewage and industrial waste effluents. This paper describes the population dynamics of TCs and FCs in relation to BOD levels in this river system. It deals in particular with the possibility of multiplication of the indicator bacteria in heavily polluted river environments.

\section{Materials and Methods}

\section{Study Area and Sample Collection}

The Tamagawa River flows through mixed mountainous, rural, suburban, and urban areas in the southwest portion of Tokyo Metropolitan Prefecture and discharges into Tokyo Bay. It has a total length of $140 \mathrm{~km}$ and a watershed area of $1240 \mathrm{~km}^{2}$. Major sources of pollution in this river system are domestic sewage and industrial waste effluents as mentioned above. The location of eight sampling stations designated in this study is illustrated in Fig. 1. Stations $\mathbf{S 1}, \mathbf{S} 2, \mathbf{S 3}$, and S4 were located on the upper streams of

*1 Department of Food Science and Technology, Tokyo University of Fisheries, Minato, Tokyo 108, Japan (平石 明・佐伯和昭・城江 進: 東京水産大学食品生産化学科).

*2 Present address: Department of Biology, Faculty of Science, Tokyo Metropolitan University, Setagaya, Tokyo 158, Japan (現所属: 東京都立大学理学部生物学科). 


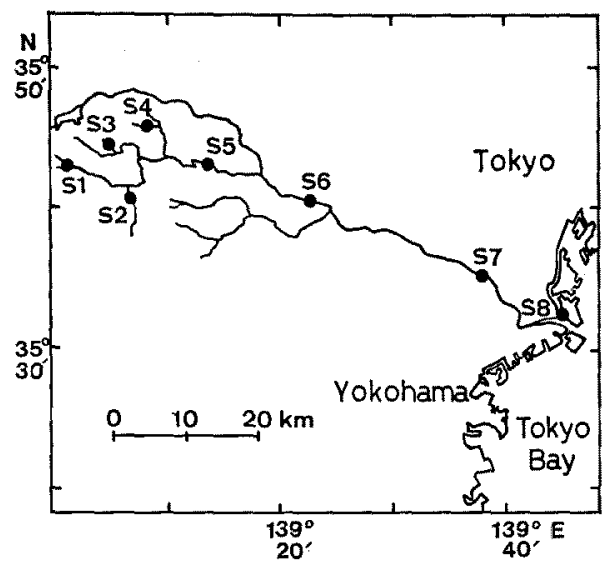

Fig. 1. Location of sampling stations on the Tamagawa River.

Akikawa, a branch of the Tamagawa River, which are mountain watershed systems at an elevation of $700 \mathrm{~m}$ above sea level. Station S5 was located on the lower stream of Akikawa in the rural area. Stations S6 and S7 were sites on the main stream in the suburban and urban areas, respectively. The remaining station $\mathbf{S 8}$ was in the estuarine system of this river.

Surface water samples were collected from each station at irregular intervals of one to four months from 1978 to 1980 . Sampling was avoided just after a heavy rainfall. The water samples were taken in sterile polyethylene bottles, stored in an insulated cooler until they arrived at the laboratory, and then prepared for testing by serial dilution with phosphate-buffered saline if necessary. This procedure was accomplished within $6 \mathrm{~h}$ after sampling.

\section{Media}

All media used for enumeration, isolation, and identification of coliforms were obtained from Eiken Chemical Co., Ltd., Tokyo. Unless otherwise indicated, these were incubated at $30^{\circ} \mathrm{C}$ when used.

\section{Enumeration and Isolation Procedures}

Total viable counts (TVC) of aerobic heterotrophic bacteria were made on Sakurai's agar ${ }^{\text {() }}$ plates. Appropriate dilutions of the water samples were spread over the agar surface and incubated at $25^{\circ} \mathrm{C}$ for 7 days before counting.

The membrane filtration technique (Millipore filter HA type; pore size, $0.45 \mu \mathrm{m}$ ) or the agar pour plate method using desoxycholate agar was used for enumerating TCs as described pre- viously. ${ }^{10)} \mathrm{TC}$ counts made at 30 and $35^{\circ} \mathrm{C}$ of incubation were recorded as presumptive 30 - and 35-TC counts, respectively. Presumed TC colonies were picked from the desoxycholate agar overlay plates and tested for gas production in brilliant green lactose bile broth tubes. Those tubes showing gas production were streaked onto eosin methylene blue agar to ensure cultural purity and then submitted to the completed test $^{10)}$ for verification. This procedure was a set of tests for morphology, Gram reaction, catalase, Kovacs' oxidase, and lactose fermentation. Finally, TC counts were obtained by correcting the presumptive counts on the basis of the results of the confirmed and completed test procedures.

FC organisms were enumerated by the elevatedtemperature desoxycholate agar plate method ${ }^{11)}$ combined with a conventional FC test. First, thermotolerant coliform colonies were obtained in the desoxycholate agar overlay incubated at $43^{\circ} \mathrm{C}$ for $20-22 \mathrm{~h}$, then these were tested for aerogenic growth in $\mathrm{EC}$ broth at $44.5^{\circ} \mathrm{C}$ for $\mathrm{FC}$ confirmation. Confirmed FC cultures were purified and submitted to the completed test as described above to correct the presumptive counts.

\section{Growth Response at Different Temperatures}

Tests for growth at 1 and $5^{\circ} \mathrm{C}$ were carried out using nutrient broth supplemented with $1 \%$ glucose, whereas growth at $44.5^{\circ} \mathrm{C}$ was determined in EC broth. These testing methods have been described previously. ${ }^{10)}$ In this study psychrotrophic and thermotolerant coliform strains were identified by their ability to grow at $1^{\circ} \mathrm{C}$ within 10 days of incubation (or $5^{\circ} \mathrm{C}$ within 4 days) and at $44.5^{\circ} \mathrm{C}$, respectively.

\section{Identification of $\mathrm{E}$. coli}

All isolated strains of thermotolerant coliforms were subjected to IMViC tests. These tests were performed using SIM medium, MR-VP broth, VP-semisolid agar, and Simmons' citrate agar. Motility and hydrogen sulfide production were concurrently determined in SIM medium. Strains showing the ++- or -+- - IMViC pattern were identified as $E$. coli.

\section{Physicohcemical Analyses}

Water temperature and $\mathrm{pH}$ were measured at the sampling stations using a theromometer and a potable electrode $\mathrm{pH}$ meter, respectively. $\mathrm{BOD}$ was determined promptly upon return to the laboratory according to the Standard Methods. ${ }^{12)}$ 


\section{Statistical Analyses}

A logarithmic transformation was made for the measured parameters except temperature before statistical analyses. Product-moment correlation coefficients, $r$, and linear regression equations (least squares) were generated on a microcomputer and tested for significance at $p<0.01$ and 0.05 by comparing them with tabulated $r$ values. ${ }^{13)}$

\section{Results}

Physicochemical and Bacteriological Characteristics

All physicochemical and bacteriological data obtained during this study are summerized in Table 1. The data recorded for water samples from stations S1, S2, S3, and S4, which were located in the mountain area remote from human habitation, apparently reflect their characteristic geographic features. The average temperature and $\mathrm{BOD}$ at the four stations were considerably lower than those at the suburban and urban stations. There was a similar tendency for the bacterial concentrations. All bacterial groups markedly increased in numbers from the upper streams toward the lower reach of this river system, and highest counts were recorded at station S8 in all cases. This station yielded 1,000 to 100,000 times more the indicator bacteria than did the stations on the mountain streams. It should be noted that 30-TC counts were higher than 35-TC counts at the stations in the mountain area, whereas no significant difference was observed between the two at the suburban and urban stations.

\section{Relationship between Indicator Bacteria and BOD}

Fig. 2 shows the statistical relationship between the concentrations of the indicator bacteria and BOD when data for the entire sampling stations were treated. The results for TVC were not statistically analyzed because of no data obtained

Table 1. Physicochemical and bacteriological data (average \pm standard deviation) for water samples from the river environment

\begin{tabular}{|c|c|c|c|c|c|c|c|c|}
\hline \multirow{2}{*}{ Station } & \multirow{2}{*}{$\begin{array}{l}\text { No. of } \\
\text { samples }\end{array}$} & \multirow{2}{*}{$\begin{array}{c}\text { Water } \\
\text { temp } \\
\left({ }^{\circ} \mathrm{C}\right)\end{array}$} & \multirow{2}{*}{$\mathrm{pH}$} & \multirow{2}{*}{$\underset{(\mathrm{mg} / l)}{\mathrm{BOD}}$} & \multicolumn{4}{|c|}{ Log no. of bacteria $/ 100 \mathrm{ml}$} \\
\hline & & & & & TVC & 30-TC & 35-TC & $\mathrm{FC}$ \\
\hline S1 & 7 & $11.5 \pm 4.0$ & $7.1 \pm 0.1$ & $0.4 \pm 0.1$ & $4.95 \pm 0.48$ & $2.34 \pm 0.39$ & $1.47 \pm 0.74$ & $0.21 \pm 0.69$ \\
\hline $\mathrm{S} 2$ & 8 & $10.8 \pm 5.3$ & $7.3 \pm 0.1$ & $0.6 \pm 0.2$ & $5.88 \pm 0.52$ & $2.54 \pm 0.37$ & $1.72 \pm 0.69$ & $0.56 \pm 0.75$ \\
\hline S3 & 5 & $10.7 \pm 4.3$ & $7.3 \pm 0.1$ & $0.7 \pm 0.3$ & $\mathrm{NT}^{*}$ & $2.21 \pm 0.42$ & $1.88 \pm 0.58$ & $0.54 \pm 0.86$ \\
\hline S4 & 5 & $10.6 \pm 4.9$ & $7.3 \pm 0.2$ & $0.6 \pm 0.3$ & $\mathrm{NT}^{*}$ & $2.11 \pm 0.90$ & $1.53 \pm 0.75$ & $0.16 \pm 0.83$ \\
\hline S5 & 6 & $14.5 \pm 6.1$ & $7.4 \pm 0.1$ & $1.9 \pm 0.4$ & $6.52 \pm 0.46$ & $3.95 \pm 0.18$ & $3.70 \pm 0.29$ & $2.51 \pm 0.44$ \\
\hline S6 & 13 & $17.1 \pm 6.6$ & $7.5 \pm 0.2$ & $3.7 \pm 1.2$ & $7.23 \pm 0.24$ & $4.59 \pm 0.26$ & $4.50 \pm 0.42$ & $3.52 \pm 0.38$ \\
\hline S7 & 13 & $19.2 \pm 5.6$ & $7.5 \pm 0.1$ & $11.9 \pm 7.4$ & $8.21 \pm 0.17$ & $5.28 \pm 0.27$ & $5.25 \pm 0.19$ & $4.60 \pm 0.24$ \\
\hline S8 & 5 & $20.2 \pm 5.3$ & $7.7 \pm 0.1$ & $12.7 \pm 5.1$ & $\mathrm{NT}^{*}$ & $6.21 \pm 0.24$ & $6.32 \pm 0.25$ & $5.62 \pm 0.27$ \\
\hline
\end{tabular}

\section{* Not tested.}

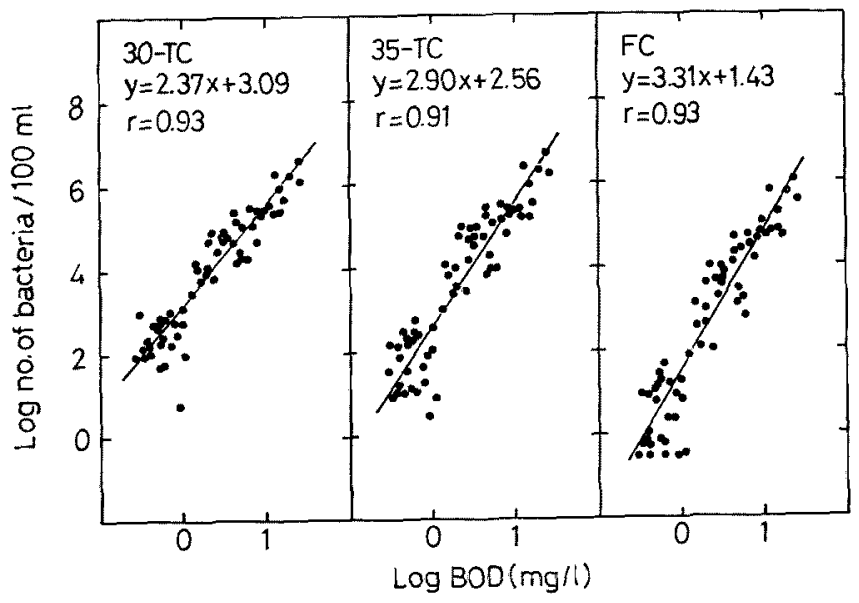

Fig. 2. Correlations between the indicator bacterial concentrations and BOD in river water. 
Table 2. Correlation coefficients between indicator bacteria and temperature or BOD at four stations

\begin{tabular}{|c|c|c|c|c|c|c|c|c|}
\hline \multirow{2}{*}{$\begin{array}{l}\text { Indicator } \\
\text { organism }\end{array}$} & \multicolumn{2}{|c|}{$\begin{array}{c}S 2 \\
(n=8)\end{array}$} & \multicolumn{2}{|c|}{$\begin{array}{c}\text { S5 } \\
(n=6)\end{array}$} & \multicolumn{2}{|c|}{$\underset{(n=13)}{S 6}$} & \multicolumn{2}{|c|}{$\begin{array}{c}S 7 \\
(n=13)\end{array}$} \\
\hline & Temp & BOD & Temp & BOD & Temp & BOD & Temp & BOD \\
\hline TVC & $0.96^{* 1}$ & -0.35 & $0.83^{* 2}$ & -0.54 & $0.77^{* 1}$ & -0.53 & -0.30 & 0.47 \\
\hline 30-TC & $0.87^{* 1}$ & -0.21 & $0.83^{* 2}$ & -0.64 & $0.81^{* 1}$ & $-0.72 * 1$ & $-0.57^{* 2}$ & 0.45 \\
\hline $35-\mathrm{TC}$ & $0.92^{* 1}$ & -0.24 & $0.77^{* 2}$ & -0.44 & $0.86^{* 1}$ & $-0.72^{* 1}$ & -0.32 & 0.44 \\
\hline $\mathrm{FC}$ & $0.90^{* 1}$ & -0.28 & $0.90^{* 1}$ & -0.56 & $0.88 * 1$ & $-0.58^{* 2}$ & -0.45 & 0.44 \\
\hline
\end{tabular}

*1 Significant at $p<0.01$.

*2 Significant at $p<0.05$.

Table 3. FC/TC ratios for water samples from the river environment*

\begin{tabular}{cccccc}
\hline \multirow{2}{*}{ Sampling station } & \multicolumn{2}{c}{ FC/30-TC } & & \multicolumn{2}{c}{ FC/35-TC } \\
\cline { 2 - 3 } \cline { 5 - 6 } & Geometric mean & Logarithmic mean & & Geometric mean & Logarithmic mean \\
\hline S1 & 0.007 & -2.13 & & 0.055 & -1.26 \\
S2 & 0.010 & -1.98 & & 0.069 & -1.16 \\
S3 & 0.021 & -1.67 & & 0.045 & -1.34 \\
S4 & 0.01 & -1.95 & & 0.043 & -1.37 \\
S5 & 0.036 & -1.44 & & 0.065 & -1.19 \\
S6 & 0.085 & -1.07 & & 0.10 & -0.98 \\
S7 & 0.21 & -0.68 & & 0.22 & -0.70 \\
S8 & 0.26 & -0.59 & & 0.23 & -0.64 \\
\hline
\end{tabular}

* Number of samples from each station is shown in Table 1.

from some stations. All of the indicator bacteria were highly correlated with BOD with the correlation coefficients, $r$, ranging from 0.91 to 0.93 , all significant at $p<0.01$. The slopes of the linear regression equations for the correlations varied between 2.37 and 3.31 , being largest for FCs.

As would be expected, there were also significant positive correlations $(p<0.01)$ among the three bacterial groups (data not shown).

Seasonal fluctuations in numbers of the indicator bacteria were found more or less at each station (data not shown). At the stations upstream from station S6, all these bacterial concentrations increased with increasing seasonal temperature. In contrast, the reamining two stations $\mathbf{S 7}$ and S8 yielded greater population densities of the indicator bacteria during the winter months than in the summer. To elucidate these results, data for representative four stations $\mathbf{S 2}, \mathbf{S 5}, \mathbf{S 6}$, and $\mathbf{S 7}$ were statistically analyzed.

Table 2 shows the correlation coefficients between all bacteriological variables and water temperature or BOD at the four stations. There were significant positive correlations between the indicator bacteria and water temperature at stations S2, S5, and S6, but such was not the case with station S7. Most of the correlations found for the bacterial concentrations and BOD were not statistically significant at $p<0.05$.

\section{Relationship between FC/TC Ratios and BOD}

Table 3 shows the FC/TC ratios recorded at the eight stations during this study. Geometric means of the FC/30-TC and FC/35-TC ratios at each station varied from 0.007 to 0.26 and from 0.043 to 0.23 , respectively. Both the ratios increased from the stations on the mountain streams toward those on the lower reach of this river system.

Fig. 3 shows the statistical relationship between the FC/30-TC and FC/35-TC ratios and BOD when developed from data for the entire sampling stations. There were significant positive correlations between the ratios and BOD at $p<0.01$.

However, at each station, no significant correlations were found between the ratios and BOD at $p<0.05$ (data not shown).

\section{Relationships of Psychrotrophic and Thermotolerant Coliforms and $B O D$}

In the previous study we suggested that thermotolerant coliforms are distributed in proportion to the degree of human waste pollution in the environment and that psychrotrophic coliforms are not related to human and other warm- 


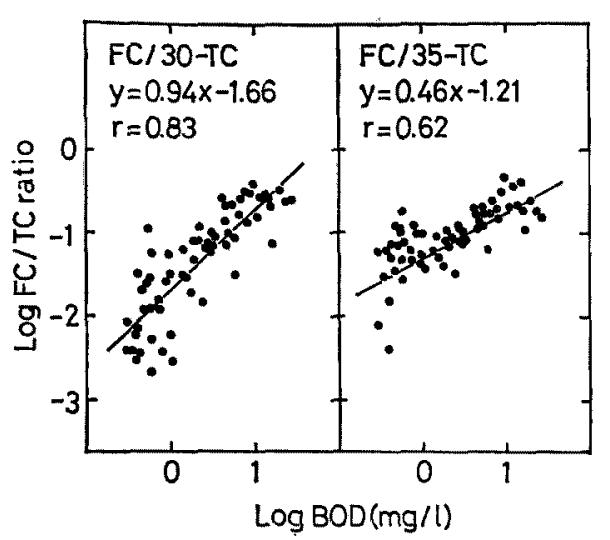

Fig. 3. Correlations between the FC/TC ratios and $B O D$ in river water.

Table 4. Incidence of psychrotrophic coliform (A), thermotolerant coliform (B), and E. coli (C) strains among $\mathrm{TC}$ and $\mathrm{FC}$ strains in relation to BOD levels*

\begin{tabular}{|c|c|c|c|c|c|c|c|}
\hline \multirow{3}{*}{$\begin{array}{c}\text { BOD } \\
\text { level } \\
(\mathrm{mg} / l)\end{array}$} & \multicolumn{7}{|c|}{$\%$ of isolates } \\
\hline & \multicolumn{3}{|c|}{$\begin{array}{l}30-\mathrm{TC} \\
\text { strains }\end{array}$} & \multicolumn{3}{|c|}{$\begin{array}{c}35-\mathrm{TC} \\
\text { strains }\end{array}$} & \multirow{2}{*}{$\frac{\begin{array}{c}\mathrm{FC} \\
\text { strains }\end{array}}{\mathrm{C}}$} \\
\hline & A & B & $C$ & A & B & $C$ & \\
\hline$<1$ & 60 & 4 & 4 & 9 & 6 & 6 & 100 \\
\hline $1-2$ & 14 & 32 & 15 & 2 & 38 & 20 & 81 \\
\hline $2-3$ & 4 & 58 & 17 & 0 & 66 & 24 & 61 \\
\hline $3-5$ & 2 & 62 & 21 & 1 & 76 & 28 & 62 \\
\hline $5-8$ & 0 & 88 & 33 & 0 & 90 & 36 & 62 \\
\hline $8<$ & 0 & 88 & 28 & 0 & 87 & 31 & 58 \\
\hline
\end{tabular}

* Results obtained with 615 30-rC, 586 35-rC, and 236 FC strains isolated from the eight stations.

blooded animal sources. ${ }^{10)}$ Since BOD levels partly reflect the degree of organic pollution associated with fecal sources in this river system, it is of great significance to observe the relationships of psychrotrophic and thermotolerant coliforms and BOD.

It is apparent from the results shown in Table 4 that psychrotrophic coliforms are major constituents of the 30-TC flora of the unpolluted stream water, although this is not true for the 35-TC flora, whereas thermotolerant coliforms constitute a large proportion of the TC population in the polluted river water. The results shown in Table 4 also indicate that the proportion of $E$. coli comprising the TC population increases with increasing BOD levels, but its relative concentration to the thermotolerant coliform or FC population decreases with increasing BOD levels.
Almost all of the isolated thermotolerant coliform and FC strains other than $E$. coli were nonmotile and gave the --++ IMViC pattern, thus being identified as Klebsiella pneumoniae.

\section{Discussion}

The results reported in this paper (Fig. 2) have shown that the indicator bacteria as well as other aerobic heterotrophic bacteria have highly significant correlations with BOD in the river system. Since the increase in BOD levels from the upper streams toward the lower reach of this river system is reflective of increasing organic pollution with inflow of domestic sewage and sanitary waste effluents, the concomitant increase in numbers of the indicator bacteria is rather a natural result.

It remains the question of whether the high concentrations of these indicator bacteria found in the urban river water result only from heavy fecal pollution. In this study we found the decrease in the proportion of $E$. coli and the contrastive increase in that of $K$. pneumoniae constituting the thermotolerant coliform or FC population with increasing BOD levels (Table 4). There is no doubt that FC organisms occurring in human feces are usually represented by $E$. coli, although not all. Thus, if the occurrence of FCs in the high-BOD river water accurately indicates recent fecal pollution, our findings might be selfcontradictory. For the above question, after all, it is logical to conclude that the high population densities of FCs in the polluted river water are due in part to regrowth of some FC members, e.g., $K$. pneumoniae, and that such FCs also greatly contribute to the high TC population contained therein. Large concentrations of FC-positive Klebsiella organisms as the result of their aftergrowth have been found in waters receiving wood pulp effluents ${ }^{14)}$ and in certain industrial organic wastes. ${ }^{15-17)}$

Evidently, the survival and levels of fecal indicator bacteria in water runoff depend not only upon trophic conditions of the aquatic environment but upon many other physicochemical conditions which change seasonally. Water temperature is one of the most important environmental factors affecting their concentrations. An inverse relationship between $E$. coli survival and water temperature has been observed in natural stream and estuary waters. ${ }^{18,19)}$ On the contrary, ANDERSon et al. ${ }^{20)}$ have recently found a 
direct relationship between the two. The present results (Table 2) would suggest that there are complicated relationships among the indicator bacteria, BOD concentration, and water temperature in a river system. The number of the indicator bacteria in natural water at a given site seems to be directly influenced by water temperature if BOD levels are relatively low. On the other hand, these bacteria would be protected by nutrients from the effects of temperature and of other physicochemical factors at such heavily polluted sites as stations S7 and S8 in this river system. Thus, it should be emphasized that the correlations between the indicator bacteria and BOD are most meaningful when developed from data for a whole river system or for heavily polluted river and estuary waters.

The results reported herein (Fig. 3) have also shown that the FC/TC ratios are highly correlated with $\mathrm{BOD}$ in the river environment, suggesting the usefulness of the ratios as pollution indicators. However, it is by no means easy to estimate their sanitary significance because the FC-TC relationship depends upon various factors such as difference in powers of survival among coliform members, source of pollution, and occurrence of psychrotrophic coliforms of nonfecal origin. An application of the FC/TC ratios to environmental monitoring therefore requires careful consideration.

Our results obtained with the distribution of psychrotrophic coliforms (Table 4) are in agreement with those described earlier ${ }^{10)}$ and plausibly explain why 30-TC counts are higher than 35-TC counts in the mountain stream water. The re-

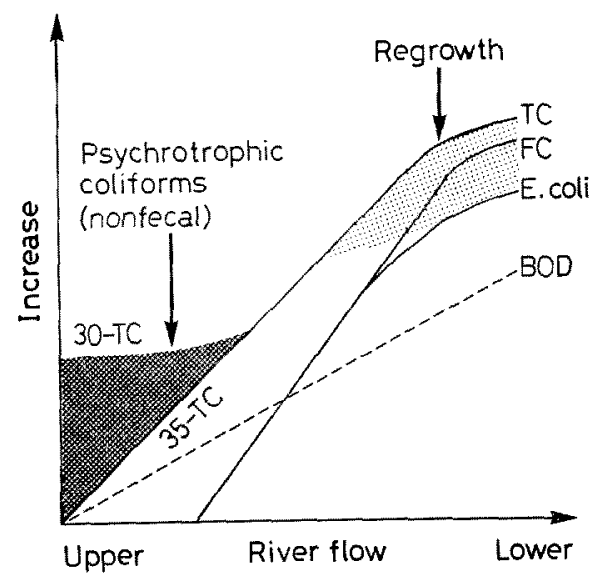

Fig. 4. Model of the relative changes in the levels of the indicator bacteria and BOD in the Tamagawa River. sults of the previous study have demonstrated that most psychrotrophic coliforms recovered from unpolluted mountain soil and stream water are taxonomically different from the common species of coliforms such as $E$. coli, Citrobacter freundii, K. pneumoniae, Enterobacter cloacae, and Enterobacter aerogenes. ${ }^{10)}$ Further studies on the taxonomic identity and actural origin of these psychrotrophs would be of considerable interest.

In the light of the results obtained so far, we propose a model of the relative changes in the levels of the indicator bacteria and BOD in the Tamagawa River system (Fig. 4).

As described herein, it is evident that TC and FC organisms have the ability to survive and even multiply in heavily polluted river and estuarine environments. This is the case in particular with $K$. pneumoniae. This fact would suggest that FC organisms as well as TCs are not always reliable indicators of recent fecal pollution or of the probable presence of enteric pathogens in nutrientrich river and estuarine environments. However, special attention should be paid to the fact that the prolonged survival of some enteric pathogens compared with that of FCs has been sometimes found in eatuary waters. ${ }^{21}$ In addition, since $K$. pneumoniae is an opportunistic pathogen in its own right, its occurrence in polluted river and estuary waters is of great concern with regard to the public health hazard.

\section{Acknowledgements}

We are grateful to S. Takii, Department of Biology, Faculty of Science, Tokyo Metropolitan University, for critical reading of the manuscript.

\section{References}

1) Y. IsHIDA: in "Eutrophication and Biological Indicators in Coastal Waters" (ed. by Japan. Soc. Sci. Fish.), Koseisha Koseikaku, Tokyo, 1982, pp. 11-26.

2) I. YASUdA and Y. IYAMA: Japan. $J$. Water Treat. Biol., 17, 1-4 (1981).

3) N. Tanaka, Y. Ueda, M. Onizawa, and $H$. Kadota: Japan. J. Liminol., 38, $41-47$ (1977).

4) Y. Tezuka, Y. Watanabe, H. Hayashi, S. FukUnaga, and M. Alzaki: Japan. J. Ecol, 24, 43-49 (1974).

5) G. A. Strobel: J. Sanit. Engng. Div., Pro. ASCE 94, 641-656 (1968).

6) E. E. Geldreich: J. Am. Water Works Assoc, 62, 113-130 (1970). 
7) ORSANCO Water Users Committee: J. Water Pollut. Control Fed., 43, 630-640 (1971).

8) T. Yoshikura, K. ODA, and S. IIDA: Bull. Japan. Soc. Sci. Fish, 46, 231-236 (1980).

9) Y. SAKURAI: J. Japan Biol. Soc. Water Wastes, 2, 21-27 (1967).

10) A. Hiraishi and S. Horie: J. Gen. Appl. Microbiol., 28, 139-154 (1982).

11) A. Hiraishi, K. Saheki, and S. Horie: Bull. Japan. Soc. Sci. Fish., 49, 1297 (1983).

12) American Public Health Association: Standard Methods for the Examination of Water and Wastewater, 14th ed., American Public Health Association, Washington D. C., 1975, pp. 543-550.

13) S. IsHII: Seibutsu Tokeigaku Nyumon (Introduction to Biostatistics), Baifukan, Tokyo, 1975, pp. 262.

14) B. E. Huntley, A. C. Jones, and V. J. Cabelli: J. Water Pollut. Control Fed., 48, 1766-1771 (1976).
15) A. P. Dufour and V.J. Cabelli: J. Water Pollut. Control Fed., 48, 872-879 (1976).

16) M. D. KNitTel, R. J. Seidler, C. Eby, and L. M. CABE: Appl. Environ. Microbiol., 34, 557-563 (1977).

17) N. R. Caplenas, M. S. Kanarek, and A. P. Dufour: Appl. Environ. Microbiol., 42, 779785 (1981).

18) G. A. McFeters and D.G. Stuart: Appl. Microbiol., 24, 805-811 (1972).

19) M. A. Faust, A. E. Aotaky, and M. T. HargaDON: Appl. Microbiol., 30, 800-806 (1975).

20) I. C. ANDERson, M. W. Rhodes, and H. I. Kator: Appl. Environ. Microbiol., 45, 1877-1883 (1983).

21) T. G. Metcalf, L.W. Slanetz, and C. H. Bartley: in "Microbial Safety of Fishery Products" (ed. by C.O. Chichester and H.D. Graham), Academic Press, New York, 1973, pp. 215-234. 